\title{
Does perioperative opioid infusion increase postoperative opioid requirement?
}

\section{Peroperatif opioid infüzyonu postoperatif opioid gereksinimini artırtr mı?}

\author{
Sevim ŞENOL KARATAŞ, Zeynep ETi, Kemal Tolga SARAÇOĞLU, Fevzi Yılmaz GÖĞÜŞ
}

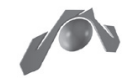

\begin{abstract}
Summary
Objectives: Opioids are the cornerstone therapy for the optimal pain management. Perioperative opioid infusion is accused of causing acute opioid tolerance, especially as the postoperative opioid requirement increases in time to provide efficient analgesia. It is debatable whether there is a difference between opioid agents regarding tolerance development. We aim to compare the effects of morphine, remifentanil and alfentanil when infused intravenously during the perioperative period.

Methods: Sixty patients undergoing elective major abdominal surgery were randomized into four groups. The four groups obtained the following treatments: saline $5 \mathrm{cc}$ iv bolus and $10 \mathrm{cc} / \mathrm{h}$ infusion for induction and maintenance in Group C, remifentanil infusion $0.25 \mu \mathrm{g} / \mathrm{kg} / \mathrm{min}$ following $1 \mu \mathrm{g} / \mathrm{kg}$ iv bolus in Group R, alfentanil infusion $0.50 \mu \mathrm{g} / \mathrm{kg} / \mathrm{min}$ following $10 \mu \mathrm{g} /$ $\mathrm{kg}$ iv bolus in Group A, and morphine infusion $0.02 \mathrm{mg} / \mathrm{kg} / \mathrm{h}$ after $0.1 \mathrm{mg} / \mathrm{kg}$ iv bolus in Group M. Meperidine $10 \mathrm{mg} / \mathrm{cc}$ iv patient-controlled analgesia was used postoperatively, and total meperidine consumptions were recorded. VAS scores and side effects were recorded during postoperative 48 hours.

Results: VAS scores in Group M were found to be significantly lower than in Group C at the $1^{\text {st }}$ postoperative hour. Twentyfour hour total meperidine consumption in Group R and Group M were significantly lower than in Group C. No statistical difference was found between groups regarding the incidence of nausea and vomiting.

Conclusion: Our study indicated that infusions of morphine, alfentanil and remifentanil administered to patients undergoing major abdominal surgery did not cause acute opioid tolerance. In contrast, infusion of morphine and remifentanil reduced postoperative opioid requirement.
\end{abstract}

Key words: Analgesia; continuous infusion; opioids; tolerance.

\section{Özet}

Amaçः Opioidler, akut ameliyat sonrası ăgrı tedavisinin temel komponentini oluşturmaktadırlar. Etkin ameliyat sonrası analjezi sağlamak için gereken opioid gereksiniminin artmasıyla, peroperatif opioid infüzyonu, akut opioid toleransı gelişimiyle suçlanmıştır. Akut opioid tolerans gelişiminin yanısıra opioid ajanlar arasında tolerans gelişimi konusunda farkliltk olup olmadığı da balen tartı̧̧malıdır. Bu çalı̧manın amacı peroperatif dönemde intravenöz infüzyon şeklinde uygulanan morfin, remifentanil ve alfentanilin etkilerinin karşılaştırılmasıdır.

Gereç ve Yöntem: Elektif majör abdominal cerrabi geçirecek, 60 hasta randomize olarak dört gruba ayrildı. Grup C'ye (kontrol) indüksiyonda iv $5 \mathrm{cc}$, idamede $10 \mathrm{cc} / \mathrm{s}$ salin infüzyonu, Grup R'ye (remifentanil) indüksiyonda iv $1 \mu \mathrm{g} / \mathrm{kg}$ bolus, idamede $0.25 \mu \mathrm{g} /$ $\mathrm{kg} / \mathrm{dk}$ remifentanil infüzyonu, Grup A'ya (alfentanil) indüksiyonda iv $10 \mu \mathrm{g} / \mathrm{kg}$ bolus, idamede $0.50 \mu \mathrm{g} / \mathrm{kg} / \mathrm{dk}$ alfentanil infüzyonu, Grup M'ye (morfin) indüksiyonda iv $0.1 \mathrm{mg} / \mathrm{kg}$ bolus, idamede $0.02 \mathrm{mg} / \mathrm{kg} / \mathrm{s}$ morfin infüzyonu uygulandi. Ameliyat sonrası analjezi için iv meperidinli hasta kontrollü analjezi (HKA) uygulandı ve toplam meperidin tüketimleri kaydedildi. Ameliyat sonrası 48 saat boyunca VAS skorları ve yan etkiler kaydedildi.

Bulgular: Grup M'ye ait VAS skorları ameliyat sonrası birinci saatte Grup C'den anlamlı olarak daba düşük bulundu. Grup $R$ ve Grup M'nin 24 saatlik toplam meperidin tüketimi Grup C'den anlamlı olarak daha düşüktü. Bulantı kusma insidansı bakımından gruplar arasinda anlamli bir fark yoktu.

Sonuç: Sonuç olarak; majör abdominal cerrabi geçiren hastalarda peroperatif dönemde üç saat süre ile uygulanan morfin, alfentanil ve remifentanil infüzyonunun ameliyat sonrası akut toleransa yol açmadığı, aksine morfin ve remifentanil infüzyonunun ameliyat sonrası opioid gereksinimini azalttı̆̆ı kanısına varılmıştır.

Anahtar sözcükler: Analjezi; devamlı infüzyon; opioidler; tolerans.

\footnotetext{
'Department of Anesthesiology, Marmara University Faculty of Medicine, Istanbul, Turkey ${ }^{1}$ Marmara Üniversitesi Tıp Fakültesi, Anesteziyoloji Anabilim Dalı, İstanbul

Submitted (Başvuru tarihi) 30.09.2013 Accepted after revision (Düzeltme sonrası kabul tarihi) 17.03.2014

Correspondence (İletişim): Dr. Zeynep Eti. Marmara Üniversitesi Tıp Fakültesi, Anesteziyoloji Anabilim Dalı, İstanbul, Turkey.

Tel: +90 - 216-327 1010 e-mail (e-posta): emineeti@superposta.com
} 


\section{Introduction}

Opioids compose the main component of acute postoperative pain management. They are also widely used during the intraoperative period as they reduce the need for inhalational anesthetic agents. ${ }^{[1]}$ However, perioperative opioid infusion is accused to result in acute opioid tolerance as the postoperative opioid requirement increases in time to provide efficient analgesia. It comes out as a decrease in drug efficacy.

Desensitization of antinociceptive system, which leads to the development of resistance against primary drug effect and sensitization of pronociceptive system, are blamed for this tolerance formation. ${ }^{[2]}$ Although acute opioid tolerance has been well-identified for many years, the results obtained from clinical and experimental studies are still controversial. ${ }^{[3-6]}$ Aguado et al. ${ }^{[3]}$ have reported that acute opioid tolerance develops in rats, and that can be prevented with the use of gabapentin. Nevertheless, another experimental study could not find any evidence in favor of acute opioid tolerance after short-term (1h) and long-term (4h) infusion of remifentanil. ${ }^{[4]}$ The fact that perioperative remifentanil infusion causes acute opioid tolerance in children undergoing elective laparoscopic ureteroneocystostomy has been reported to be associated with the infusion dose. ${ }^{[5]}$ In addition to the development of acute opioid tolerance, it is still a debatable topic whether there is a difference between opioid agents regarding tolerance development or not. ${ }^{[6]}$

This prospective, randomized, placebo-controlled double-blind study aimed to compare the effects of morphine, remifentanil and alfentanil which were infused intravenously during perioperative period.

\section{Materials and Methods:}

Following the approval of the ethics committee and patients' written informed consents, 60 American Society of Anesthesiology (ASA) 1-2 patients, between the ages of 20-60 years, and undergoing elective major abdominal surgery, were recruited in the study. Exclusion criteria consisted of patient refusal, hypersensitivity to opioids, preoperative opioid use, complications during surgery, side effects of opioid therapy such as respiratory depression, severe nau- sea and vomiting, and itching. All patients received $0.015 \mathrm{mg} / \mathrm{kg}$ atropine sulphate and $0.07 \mathrm{mg} / \mathrm{kg}$ midazolam IM as a premedication $45 \mathrm{~min}$ before surgery. Anesthesia was induced with thiopental sodium $5 \mathrm{mg} / \mathrm{kg}$ and vecuronium $0.1 \mathrm{mg} / \mathrm{kg}$ iv and was maintained with $1 \mathrm{MAC}$ desflurane and $70 \%$ nitrous oxide in oxygen. All patients received $1 \mathrm{~g}$ of intravenous paracetamol intraoperatively.

Patients were randomized into four groups by using opaque envelopes. The anesthetist was blind to the opioid solution infused during general anesthesia. The control group (Group C) was administered normal saline $5 \mathrm{cc}$ bolus and $10 \mathrm{cc} / \mathrm{h}$ infusion for induction and maintenance respectively. The remifentanil group (Group R) was administered remifentanil $1 \mu \mathrm{g} / \mathrm{kg}$ iv bolus for induction and $0.25 \mu \mathrm{g} / \mathrm{kg} /$ min infusion for maintenance. The alfentanil group (Group A) was administered alfentanil $10 \mu \mathrm{g} / \mathrm{kg}$ iv bolus and $0.50 \mu \mathrm{g} / \mathrm{kg} / \mathrm{min}$ infusion for induction and maintenance of anesthesia, respectively. The morphine group (Group M) received morphine 0.1 $\mathrm{mg} / \mathrm{kg}$ iv bolus for induction and $0.02 \mathrm{mg} / \mathrm{kg} / \mathrm{h}$ infusion for maintenance. During the surgery, the opioid infusion rate was kept constant and we changed the desflurane concentration if necessary. The infusions were terminated at the beginning of the closure of the skin incision.

Every half hour during the operation desflurane concentrations were recorded. Total opioid consumption and the time of recovery were recorded at the end of the surgery. Recovery time is described as the time between the termination of inhalational anesthetic agents and the time patients obey the commands.

In the recovery room for postoperative analgesia, meperidine $1 \mathrm{mg} / \mathrm{kg}$ iv was administered to provide a Visual Analogue Scale (VAS) $\leq 30$, and meperidine $(10 \mathrm{mg} / \mathrm{cc})$ iv patient-controlled analgesia (PCA) was started with a bolus dose of $1.5 \mathrm{cc}$ and a lockout time of $8 \mathrm{~min}$. VAS scores and side effects (nausea, vomiting, and itching, respiratory depression) were recorded at postoperative $1,2,4,8,12$, 16, 24, 36 and 48th hours. Meperidine consumptions were noted in the postoperative first 48 hours. The primary outcome variable was the consumption of meperidine in the postoperative period. To dem- 
Table 1. Patient characteristics and duration of surgery (Mean \pm SD)

\begin{tabular}{lcccc}
\hline & Group C & Group R & Group A & Group M \\
\hline Age (year) & $53.93 \pm 10.63$ & $49.00 \pm 9.37$ & $54.68 \pm 9.85$ & $48.31 \pm 11.84$ \\
Weight (kg) & $64.56 \pm 9.42$ & $67.93 \pm 14.21$ & $69.43 \pm 10.63$ & $68.75 \pm 17.32$ \\
Gender (male/female) & $5 / 11$ & $3 / 13$ & $4 / 12$ & $3 / 13$ \\
Duration of surgery (min) & $126.87 \pm 58.16$ & $121.25 \pm 38.27$ & $124.62 \pm 51.90$ & $146.25 \pm 77.0$ \\
\hline
\end{tabular}

Table 2. Desflurane levels (\%) (Mean \pm SD)

\begin{tabular}{lcccc}
\hline & Group C & Group R & Group A & Group M \\
\hline 15. $\min$ & $6.00 \pm 0.0$ & $4.70 \pm 1.41^{\dagger}$ & $5.18 \pm 1.47$ & $5.90 \pm 0.31$ \\
30. $\min$ & $6.00 \pm 0.0$ & $5.20 \pm 1.13$ & $4.81 \pm 1.25$ & $5.70 \pm 0.67$ \\
60. $\min$ & $5.75 \pm 0.46$ & $5.10 \pm 0.99$ & $4.81 \pm 1.16 \dagger$ & $5.70 \pm 0.67$ \\
$90 . \min$ & $5.87 \pm 0.35$ & $4.30 \pm 0.82^{\dagger}$ & $5.09 \pm 1.22 \dagger$ & $5.90 \pm 0.31$ \\
120. $\min$ & $6.00 \pm 0.0$ & $4.50 \pm 0.84^{\dagger}$ & $5.00 \pm 1.18 \dagger$ & $5.80 \pm 0.63$ \\
\hline
\end{tabular}

${ }^{\dagger}$ Between groups $p<0.05$.

Table 3. Visual Analogue Scale scores ( $\mathrm{mm})($ Mean \pm SD)

\begin{tabular}{lcccc}
\hline & Group C & Group R & Group A & Group M \\
\hline 1. h & $22.93 \pm 7.16$ & $20.62 \pm 5.36$ & $21.25 \pm 6.63$ & $15.75 \pm 7.30^{\dagger}$ \\
2. h & $19.93 \pm 5.43$ & $21.12 \pm 6.82$ & $17.56 \pm 8.62$ & $15.00 \pm 7.18$ \\
4. h & $18.06 \pm 5.05$ & $18.93 \pm 5.88$ & $16.25 \pm 7.12$ & $13.56 \pm 6.12$ \\
6. h & $16.75 \pm 4.53$ & $16.87 \pm 7.54$ & $17.06 \pm 8.23$ & $14.43 \pm 4.61$ \\
8. h & $16.06 \pm 7.58$ & $14.87 \pm 6.82$ & $14.25 \pm 7.22$ & $14.68 \pm 4.25$ \\
12. h & $14.62 \pm 6.57^{*}$ & $13.56 \pm 8.10$ & $13.00 \pm 6.00$ & $11.18 \pm 5.63$ \\
24. h & $14.50 \pm 6.78^{*}$ & $10.56 \pm 6.95^{*}$ & $10.62 \pm 7.90^{*}$ & $12.87 \pm 6.30$ \\
36. h & $12.75 \pm 6.07^{*}$ & $9.56 \pm 6.36^{*}$ & $6.87 \pm 6.16^{*}$ & $9.68 \pm 4.93^{*}$ \\
48. h & $9.62 \pm 4.47^{*}$ & $7.25 \pm 6.90^{*}$ & $7.00 \pm 6.27^{*}$ & $11.37 \pm 7.35^{*}$ \\
\hline
\end{tabular}

*Inside the groups $p<0.05$; ${ }^{+}$Between the groups $p<0.05$.

onstrate a $25 \%$ difference in initial $48-\mathrm{h}$ meperidine consumption, we estimated that 15 patients per group would be required for $\alpha=0.05$ and $\beta=0.2$ (power 80\%). All statistical analyses were performed using SPSS (Statistical Package for Social Sciences) for Windows 10.0. In comparison of descriptive statistical methods (average, standard deviation) and quantitative data, we tested normal distributed data with one-way ANOVA test and the Student $\mathrm{t}$ test. We analyzed non-normal distributed data with Kruskal Wallis and Mann-Whitney U tests. Quantitative data were compared using Chi-Square test. A p value $<0.05$ was considered as statistically significant.

\section{Results}

No statistical difference was found between the groups regarding the demographical data and the duration of the surgery $(\mathrm{p}>0.05)$ (Table 1$)$. There was no statistical difference inside the groups regarding the preoperative desflurane concentrations $(p>0.05)$. There was a statistically significant decrease of desflurane concentration in Group $\mathrm{R}$ at $15^{\text {th }}, 90^{\text {th }}$ and $120^{\text {th }}$ min compared to Group C and Group $\mathrm{M}$ and in Group A after 30th min compared to Group C and Group M ( $<<0.05)$ (Table 2).

Total opioids infused during perioperative period were as follows: $1.75 \pm 0.6 \mathrm{mg}$ remifentanil in 
Table 4. Postoperative meperidine consumption (mg) (Mean \pm SD)

\begin{tabular}{lcccc}
\hline & Group C & Group R & Group A & Group M \\
\hline Recovery unit & $74.68 \pm 19.18$ & $88.12 \pm 29.54$ & $78.12 \pm 23.79$ & $70.93 \pm 15.72$ \\
1. h & $1.96 \pm 2.72$ & $1.71 \pm 2.35$ & $1.03 \pm 1.61$ & $0.65 \pm 1.44$ \\
2. h & $5.90 \pm 4.69$ & $4.94 \pm 3.17$ & $4.96 \pm 4.60$ & $2.90 \pm 2.20$ \\
4. h & $13.34 \pm 8.21$ & $10.28 \pm 4.26$ & $11.53 \pm 6.66$ & $6.43 \pm 5.81^{\dagger}$ \\
6. h & $18.62 \pm 9.08$ & $14.50 \pm 6.04$ & $17.90 \pm 7.94$ & $8.53 \pm 6.69^{\dagger}$ \\
8. h & $22.90 \pm 11.15$ & $18.55 \pm 7.62$ & $23.53 \pm 10.05$ & $11.40 \pm 8.08^{+}$ \\
12. h & $32.37 \pm 13.60$ & $25.86 \pm 13.61$ & $28.53 \pm 12.33$ & $15.28 \pm 8.93^{\dagger}$ \\
24. h & $56.65 \pm 21.40$ & $40.14 \pm 19.97^{\dagger}$ & $48.43 \pm 17.78$ & $29.85 \pm 10.59^{\dagger}$ \\
36. h & $77.84 \pm 31.24$ & $49.75 \pm 24.65^{\dagger}$ & $65.71 \pm 25.19$ & $40.47 \pm 15.82^{\dagger}$ \\
48. h & $98.56 \pm 35.45$ & $66.56 \pm 34.96^{\dagger}$ & $81.15 \pm 29.25$ & $53.93 \pm 20.01^{\dagger}$
\end{tabular}

${ }^{*}$ Inside groups $p<0.05$; ${ }^{+}$Between groups $p<0.05$.

Table 5. Nausea and vomiting incidence

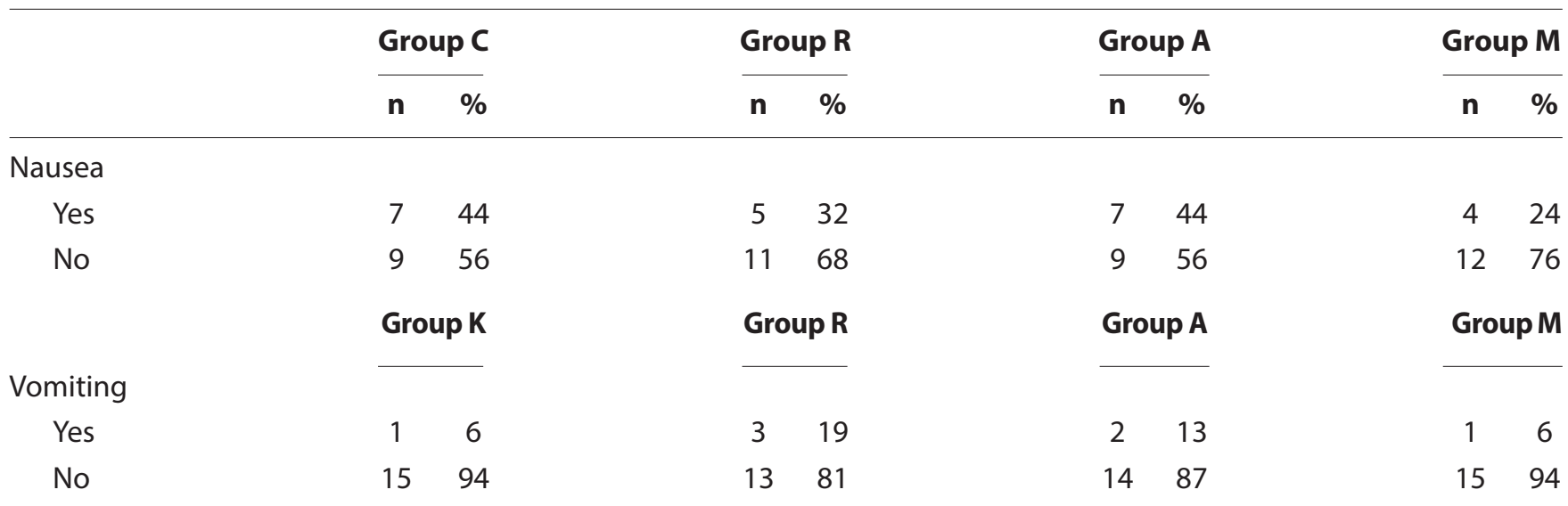

Group R, 4.24 $2.06 \mathrm{mg}$ alfentanil in Group A, and $3.08 \pm 1.53 \mathrm{mg}$ morphine in Group M. Recovery time was found to be $12.50 \pm 6.72 \mathrm{~min}$ in control group, $15.31 \pm 11.47 \mathrm{~min}$ in Group R, 17.50 \pm 7.82 min in Group A, and 21.56 $10.11 \mathrm{~min}$ in Group M. It was found significantly longer in Group $M$ compared to Group C $(\mathrm{p}<0.05)$.

VAS scores of Group M were found to be significantly lower than Group C at the $1^{\text {st }}$ hour $(\mathrm{p}<0.05)$. There was not a significant difference between groups at other measurement times ( $>0.05$ ) (Table 3). No difference was found between groups regarding the required loading dose of meperidine in the recovery unit ( $>0.05)$ (Table 4). PCA meperidine consumption of Group R was lower compared to Group C after $24^{\text {th }}$ hour. Twenty four-hour total meperidine consumptions of Group R and Group $\mathrm{M}$ were significantly lower than Group C $(\mathrm{p}<0.05)$ (Table 4).
No statistical difference was found between groups regarding the incidence of nausea and vomiting (p>0.05) (Table 5). No other side effect was observed in patients other than nausea and vomiting.

\section{Discussion}

It was found in the current study that perioperative infusion of alfentanil, remifentanil and morphine did not lead to any increase in postoperative opioid requirement. Besides, infusion of morphine and remifentanil reduced the postoperative opioid requirement.

In the presence of acute tolerance, the required dose of a pharmacological agent increase to sustain its therapeutic effect. It is widely accepted that chronic opioid therapy is associated with the development of pharmacological tolerance. Nonetheless, acute 
tolerance development after short-time infusion is a debatable issue. Acute opioid tolerance was indicated in several experimental studies. ${ }^{[3,7,8]}$ Although acute opioid tolerance was concluded to be observed in studies including healthy subjects and patients receiving high dose opioids during anesthesia, its presence is still controversial. ${ }^{[9,10]}$

Regarding the development of opioid tolerance, there are great differences between the results of the studies employing animal models and the studies including patients with pain. ${ }^{[11-13]}$ While a study carried out administering $8 \mathrm{~h}$ morphine infusion to dogs and mice showed that the analgesic effect of morphine potently decreased, ${ }^{[14,15]}$ another rat study reported that prolonged remifentanil infusion did not cause acute analgesic tolerance. ${ }^{[4]}$ Schraag et al. $^{[16]}$ reported that neither alfentanil infusion given to 51 patients undergoing cardiac surgery nor remifentanil infusion administered to 30 patients undergoing orthopedic surgery led to the development of opioid tolerance. These contradictory results may suggest that the methods used for pain assessment are different for humans and animals. The assessment method used for humans is based on the principle that pain is expressed by the patient. When the degree of pain in animals are evaluated, pain behaviors are observed and pain assessment is indirectly analyzed according to these behaviors. As Mogil and Crager ${ }^{[17]}$ indicated, assessing opioid analgesic tolerance on animal models may not produce reliable results because of the fact that pain behaviors include not only the nociceptive component but also the psychomotor component. In light of these results, our study has an advantage over other studies regarding precise assessment of acute opioid tolerance as our study examined the patients with postoperative pain.

Both the study subjects (whether the study is carried out on animals or humans) and the pain characteristics (whether it is clinical pain or experimental pain) have a role in obtaining different results. Vinik and Kissin ${ }^{[18]}$ administered remifentanil infusion on 13 volunteers having experimentally created pain and indicated that these patients quickly developed tolerance against analgesia. Different pain modalities are created with experimental pain models. They ensure the standardization of painful stimulants; how- ever, the pain is different from the clinical pain. In order to eliminate the difference mentioned above, in their study $\mathrm{Ho}$ et al. ${ }^{[19]}$ performed abdominal surgery on rats, and thus, generated clinical pain. In this way, they indicated that postoperative pain prevented the development of opioid tolerance. However, it is not known exactly how surgical pain prevented acute opioid tolerance. The activation of the hypothalamic-pituitary-adrenal axis with stress, direct effect of ACTH or corticosteroids may be suggested to reduce the effect of the formation of acute morphine tolerance. ${ }^{[20-22]}$ Considering these results and the fact that our study recruited the patients having clinical pain after surgery, it can be claimed that our study is more advantageous than other studies regarding precise assessment of acute opioid tolerance.

Because of various methods used in the assessment of analgesia and in drug administration, opioid tolerance may develop in different ways. ${ }^{[23]}$ For instance, in a study examining intrinsic effects of opioid tolerance for different dose regimes it was found that continuous infusion led to opioid tolerance development in a completely different way as compared to intermittent infusion. ${ }^{[2]}$ Also, the wide range of opioid application including acute/ chronic, spinal/supraspinal, and bolus injection/infusion plays a role in the occurrence of disparities in tolerance development. ${ }^{[24-26]}$ There are publications showing the fact that opioid infusion facilitates the development of acute opioid tolerance. ${ }^{[10,27]}$ However, in a study by Kissin et al. ${ }^{[28]}$ a group of rats was administered a single dose sc morphine while the other group was given morphine infusion, and both groups developed acute opioid tolerance after the administration. On the other hand, continuous morphine infusion has been reported to cause higher rate of opioid tolerance compared to intermittent infusion and single-dose of morphine. ${ }^{[29,30]}$

Although the degree of opioid tolerance is not related to the potency of the opioid, ${ }^{[31]}$ formation rate depends upon the pharmacokinetics and pharmacodynamics of the opioid. ${ }^{[23]}$ It was observed that particularly short-acting opioids develop tolerance. Tolerance development is more rapid especially when the short-acting opioids are used. Also, the short-acting opioids remifentanil and alfentanil are 
suggested to rapidly cause opioid tolerance. ${ }^{[32,33]} \mathrm{Al}$ fentanil provides the balanced blood concentration in a shorter time in comparison to all other opioids used as infusion. However, we did not find any difference between the opioids used in the study regarding tolerance formation.

Another factor that influences the formation and degree of tolerance is the dose of opioids. As opioid tolerance is related to pharmacodynamics, dependence on opioid dose is not surprising. ${ }^{[34]}$ It was proposed that when high-dose of opioid was used, acute opioid tolerance developed more rapidly. ${ }^{[8]}$ Chia et al. ${ }^{[35]}$ compared the effects of low-dose $(1 \mu \mathrm{gr} / \mathrm{kg})$ and high-dose $(15 \mu \mathrm{gr} / \mathrm{kg})$ of fentanil on acute opioid tolerance in patients undergoing total abdominal hysterectomy. In that study, they indicated that postoperative opioid requirement was higher in the group receiving high-dose fentanil. In addition, a study conducted by Marshall et al. ${ }^{[36]}$ reported that patients who were administered high-dose morphine infusion required more opioid in the postoperative period. Similarly, Joly et al. ${ }^{[37]}$ indicated that postoperative pain scores were higher in patients undergoing colorectal-surgery and received high-dose remifentanil. Another study showed that approximately 3-h infusion of remifentanil caused acute tolerance in children. ${ }^{[5]}$ However, it was reported that this effect occurred with the doses of $0.6-0.9 \mathrm{mcg} / \mathrm{kg} / \mathrm{min}$, and patients receiving $0.3 \mathrm{mcg} / \mathrm{kg} / \mathrm{min}$ remifentanil infusion did not develop tolerance.

In the current study, we compared the groups receiving infusions of morphine, remifentanil and alfentanil with the control group and with one another. We used equivalant doses of opioids which are different in terms of potency and action time. We employed the visual analog scale in order to provide the most objective method for the assessment of postoperative pain levels, and determined the postoperative opioid requirement using the PCA method. None of the groups developed opioid tolerance in the postoperative period. In contrast, opioid consumption was found to be significantly lower especially in the morphine group as compared to the control group.

In conclusion, our study indicated that infusions of morphine, alfentanil and remifentanil administered to patients undergoing major abdominal surgery did not cause acute opioid tolerance. In contrast, infusion of morphine and remifentanil reduced the postoperative opioid requirement.

\section{Conflict-of-interest issues regarding the author- ship or article: None declared.}

\section{Peer-rewiew: Externally peer-reviewed.}

\section{References}

1. Aguado D, Abreu M, Benito J, Garcia-Fernandez J, Gómez de Segura IA. Effects of naloxone on opioid-induced hyperalgesia and tolerance to remifentanil under sevoflurane anesthesia in rats. Anesthesiology 2013;118(5):1160-9. CrossRef

2. Angst MS, Clark JD. Opioid-induced hyperalgesia: a qualitative systematic review. Anesthesiology 2006;104(3):570-87.

3. Aguado D, Abreu M, Benito J, Garcia-Fernandez J, Gómez de Segura IA. The effects of gabapentin on acute opioid tolerance to remifentanil under sevoflurane anesthesia in rats. Anesth Analg 2012;115(1):40-5. CrossRef

4. Ishii $H$, Petrenko $A B$, Kohno $T$, Baba $H$. No evidence for the development of acute analgesic tolerance during and hyperalgesia after prolonged remifentanil administration in mice. Mol Pain 2013;9:11. CrossRef

5. Kim SH, Lee $M H$, Seo H, Lee IG, Hong JY, Hwang JH. Intraoperative infusion of $0.6-0.9 \mu \mathrm{g} \cdot \mathrm{kg}(-1) \cdot \min (-1)$ remifentanil induces acute tolerance in young children after laparoscopic ureteroneocystostomy. Anesthesiology 2013;118(2):337-43.

6. Grecksch G, Just S, Pierstorff C, Imhof AK, Glück L, Doll C, et al. Analgesic tolerance to high-efficacy agonists but not to morphine is diminished in phosphorylation-deficient S375A $\mu$-opioid receptor knock-in mice. J Neurosci 2011;31(39):13890-6. CrossRef

7. Bobeck EN, Haseman RA, Hong D, Ingram SL, Morgan MM. Differential development of antinociceptive tolerance to morphine and fentanyl is not linked to efficacy in the ventrolateral periaqueductal gray of the rat. J Pain 2012;13(8):799807. CrossRef

8. Aguado D, Abreu M, Benito J, García-Fernández J, Gómez de Segura IA. Ketamine and remifentanil interactions on the sevoflurane minimum alveolar concentration and acute opioid tolerance in the rat. Anesth Analg 2011;113(3):505-12.

9. Luginbühl M, Gerber A, Schnider TW, Petersen-Felix S, Arendt-Nielsen L, Curatolo M. Modulation of remifentanil-induced analgesia, hyperalgesia, and tolerance by small-dose ketamine in humans. Anesth Analg 2003;96(3):726-32. CrossRef

10. Crawford MW, Hickey C, Zaarour C, Howard A, Naser B. Development of acute opioid tolerance during infusion of remifentanil for pediatric scoliosis surgery. Anesth Analg 2006;102(6):1662-7. CrossRef

11. Gustorff B, Nahlik G, Hoerauf KH, Kress HG. The absence of acute tolerance during remifentanil infusion in volunteers. Anesth Analg 2002;94(5):1223-8. CrossRef

12. Lilius TO, Rauhala PV, Kambur O, Kalso EA. Modulation of morphine-induced antinociception in acute and chronic opioid treatment by ibudilast. Anesthesiology 2009;111(6):1356-64.

13. Gómez de Segura IA, de la Vibora JB, Aguado D. Opioid tolerance blunts the reduction in the sevoflurane minimum alveolar concentration produced by remifentanil in the rat. 
Anesthesiology 2009;110(5):1133-8. CrossRef

14. Martin WR, Eades CG. Demonstration of tolerance and physical dependence in the dog following a short-term infusion of morphine. J Pharmacol Exp Ther 1961;133:262-70.

15. Cox BM, Ginsburg M, Osman $\mathrm{OH}$. Acute tolerance to narcotic analgesic drugs in rats. $\mathrm{Br} J$ Pharmacol Chemother 1968;33(2):245-56. CrossRef

16. Schraag S, Checketts MR, Kenny GN. Lack of rapid development of opioid tolerance during alfentanil and remifentanil infusions for postoperative pain. Anesth Analg 1999;89(3):753-7. CrossRef

17. Mogil JS, Crager SE. What should we be measuring in behavioral studies of chronic pain in animals? Pain 2004;112(12):12-5. CrossRef

18. Vinik HR, Kissin I. Rapid development of tolerance to analgesia during remifentanil infusion in humans. Anesth Analg 1998;86(6):1307-11. CrossRef

19. Ho ST, Wang JJ, Liaw WJ, Lee HK, Lee SC. Surgical pain attenuates acute morphine tolerance in rats. $\mathrm{Br} J$ Anaesth 1999;82(1):112-6. CrossRef

20. Asl BH, Hassanzadeh K, Khezri E, Mohammadi S. Evaluation the effects of dextromethorphan and midazolam on morphine induced tolerance and dependence in mice. Pak J Biol Sci 2008;11(13):1690-5. CrossRef

21. Esmaeili Mahani S, Motamedi F, Javan M, Ahmadiani A. Involvement of hypothalamic pituitary adrenal axis on the effects of nifedipine in the development of morphine tolerance in rats. Pharmacol Biochem Behav 2005;81(1):152-7.

22. Iwai S, Kiguchi N, Kobayashi Y, Fukazawa Y, Saika F, Ueno $\mathrm{K}$, et al. Inhibition of morphine tolerance is mediated by painful stimuli via central mechanisms. Drug Discov Ther 2012;6(1):31-7. crossRef

23. Dumas EO, Pollack GM. Opioid tolerance development: a pharmacokinetic/pharmacodynamic perspective. AAPS J 2008;10(4):537-51. CrossRef

24. Madia PA, Dighe SV, Sirohi S, Walker EA, Yoburn BC. Dosing protocol and analgesic efficacy determine opioid tolerance in the mouse. Psychopharmacology (Berl) 2009;207(3):413-22.

25. Mattioli TA, Sutak M, Milne B, Jhamandas K, Cahill CM. Intrathecal catheterization influences tolerance to chronic morphine in rats. Anesth Analg 2012;114(3):690-3. CrossRef

26. Carvalho B, Drover DR, Ginosar Y, Cohen SE, Riley ET. Intrathe- cal fentanyl added to bupivacaine and morphine for cesarean delivery may induce a subtle acute opioid tolerance. Int J Obstet Anesth. 2012;21(1):29-34. CrossRef

27. Guignard B, Bossard AE, Coste C, Sessler DI, Lebrault C, Alfonsi $P$, et al. Acute opioid tolerance: intraoperative remifentanil increases postoperative pain and morphine requirement. Anesthesiology 2000;93(2):409-17. CrossRef

28. Kissin I, Brown PT, Robinson CA, Bradley EL Jr. Acute tolerance in morphine analgesia: continuous infusion and single injection in rats. Anesthesiology 1991;74(1):166-71. CrossRef

29. Dighe SV, Madia PA, Sirohi S, Yoburn BC. Continuous morphine produces more tolerance than intermittent or acute treatment. Pharmacol Biochem Behav 2009;92(3):537-42.

30. Le Marec T, Marie-Claire C, Noble F, Marie N. Chronic and intermittent morphine treatment differently regulates opioid and dopamine systems: a role in locomotor sensitization. Psychopharmacology (Berl) 2011;216(2):297-303. CrossRef

31. Kissin I, Brown PT, Bradley EL Jr. Magnitude of acute tolerance to opioids is not related to their potency. Anesthesiology 1991;75(5):813-6. CrossRef

32. Stricker PA, Kraemer FW, Ganesh A. Severe remifentanil-induced acute opioid tolerance following awake craniotomy in an adolescent. J Clin Anesth 2009;21(2):124-6. CrossRef

33. Kissin I, Bright CA, Bradley EL Jr. Acute tolerance to continuously infused alfentanil: the role of cholecystokinin and $\mathrm{N}$-methyl-D-aspartate-nitric oxide systems. Anesth Analg 2000;91(1):110-6. CrossRef

34. Freye E, Latasch L. Development of opioid tolerance -- molecular mechanisms and clinical consequences. [Article in German] Anasthesiol Intensivmed Notfallmed Schmerzther 2003;38(1):14-26. [Abstract] CrossRef

35. Chia YY, Liu K, Wang JJ, Kuo MC, Ho ST. Intraoperative high dose fentanyl induces postoperative fentanyl tolerance. Can J Anaesth 1999;46(9):872-7. CrossRef

36. Marshall $\mathrm{H}$, Porteous $C$, McMillan I, MacPherson SG, Nimmo WS. Relief of pain by infusion of morphine after operation: does tolerance develop? Br Med J (Clin Res Ed) 1985;291(6487):19-21. CrossRef

37. Joly V, Richebe P, Guignard B, Fletcher D, Maurette P, Sessler $\mathrm{DI}$, et al. Remifentanil-induced postoperative hyperalgesia and its prevention with small-dose ketamine. Anesthesiology $2005 ; 103(1): 147-55$. CrossRef 